\title{
USER INTERFACE ANALYSIS OF GAPURA UNIVERSITAS MULTIMEDIA NUSANTARA WEBSITE
}

\author{
Dara Shafira Zahra ${ }^{1}$ \\ Wella $^{2}$ \\ Aditya Satyagraha ${ }^{3}$
}

\author{
Accepted May. o6, 2021; Approved July. 13, 2021
}

\begin{abstract}
The user interface (UI) of the Gapura site is proven to have various problems such as a poor visual hierarchy, UI that confuses its users, and UI that are considered unattractive by users. These things result in the poor feedback of its users. This study aims to examine the problems in the Gapura site by using the guidelines of the e-book published by UXPin, "Web UI Best Practice". The series of tests that will be conducted are blur test, scenario test, questionnaire and survey. After that, a prototype will be built according to the results of the tests with the aim of improving the UI Gapura site. The results of the prototypes made show that while there are still mistakes regarding the visual hierarchy of the prototype, the prototype was proven to be more usable by the users, and received better feedback than the Gapura site. Thus, it can be concluded that the changes applied in the prototype has made the UI of Gapura better.
\end{abstract}

Keywords: user interface; uxpin; web ui design; web ui prototype; ui evaluation

\section{Introduction}

Website user interface design is often misinterpreted as the appearance of the site's interface display. Interface isn't only about shapes and colors, but also about the presentation using the right tools for the user so that the users can achieve their goals. Interface of a website would also trigger some kind of feeling, whether it's familiar and comfortable feeling that's found from using the site, or merely becoming a site that the users would only

${ }^{1}$ Dara Shafira Zahra is an alumni at Faculty of Information and Technology, Universitas Multimedia Nusantara (UMN) Tangerang.

${ }^{2}$ Wella is a lecturer at Faculty of Information and Technology, Universitas Multimedia Nusantara (UMN) Tangerang.

${ }^{3}$ Aditya Satyagraha is a lecturer at Faculty of Art and Design, Universitas Multimedia Nusantara (UMN) Tangerang. visit only when they absolutely have to (UXPin., 2014), (UXPin., 2015), (UXPin., 2017). Professionals that dwells in creative media that involves product designs, entertainments, site designs, marketing, and communication have begun to consider the importance of triggering some kind of feeling and personality in communication to capture the customer's attention and create a satisfying experience. In every step of designing, a designer has a goal to complete the needs of their clients, which means that their design has to be

e-mail :dara.zahra@umn.ac.id

e-mail:wella@umn.ac.id

e-mail: aditya.satyagraha@umn.ac.id 
usable, understandable or user-friendly, and interesting and attractive (Trevor van Gorp \& Edie Adams, 2012). The level of attractiveness would especially matter when the user has the choice between two or more products that have the same level of usability and user-friendliness (Eldesouky, 2013), (Rouse, 2016). Two messages that contain the same words could convey different messages should the color, formation, and the shape designs of said messages are changed. Thus, it is crucial for the designer to design a design that can convey the right messages so that there would be no misunderstanding (Weinschenk, 2011).

Universitas Multimedia Nusantara or UMN is a private university that's established in 2006 by Kompas Gramedia Group that focuses in Multimedia-related majors. UMN has a vision to become a leading tertiary institution in the field of ICT, both at national and international levels, and a mission to participate in educating the nation and advancing the welfare of the nation through efforts to organize higher education by implementing the Tridarma of Universities. UMN has a variety of facilities both offline and online to help its students, one of which is the Gapura site which is useful for helping students make room reservations, printing documents, etc.

Based on the initial questionnaire to find out the errors and user responses regarding the UI of the Gapura site, it can be concluded that the Gapura site has errors in terms of the visual hierarchy which impacts highly in the understanding of users when using the site. The UI of Gapura site is also considered unattractive and confusing by the users. After knowing the definition and importance of UI, UI improvement suggestions will be made a prototype of the interface of the site Gapura which proved unfavorable using an electronic book guide "Web UI Design Best Practices" by UXPin (2017).
According to Tara Matthews, Tejinder K. Judge and Steve Whittaker (2012), the usage of persona in the designing process could greatly help the designing of UI and $\mathrm{UX}$, however this factor is determined by the designer's level of understanding regarding persona. Furthermore, according to Alexandru Tugui (2011)'s experiment on calm technology, it's proven that by using the WYWWYWI (What You Want, When You Want It) principle, he managed to create a sense of freedom to the user that also increases the user's comfortability upon using the product. Lastly, according to Andreas Sonderegger and Juergen Sauer (2009), it is proven that the aesthetic of a product impacts on the user's perception of the product's usability.

\section{Methodology}

A. Object of Research

The object in this study is the Gapura website. The factor that will be the focus of this research is the UI display of the website based on the results of the questionnaire and observations that will be carried out to the users of the site. All data taken comes from websites based on the agreement of the site.

\section{B. Research Data Sampling}

Using the Slovin formula (Stephanie, 2012) with an error tolerance of $5 \%$, from the total population of 385 new students from the Informatics Engineering Faculty, it was found that the number of sampling where the object of research will be tested was 196 people. While the prototype results will be evaluated by means of observations, questionnaires and surveys to students who have used the Gapura site before to find out whether the prototype is better than the current Gapura site. Using the Pareto efficient formula which says that $80 \%$ of the total number can be represented by $20 \%$ of the total number, 
the sample evaluation number of this prototype is $20 \%$ of 197 people, which is 40 people.

\section{Research Method}

To determine the errors and faults in the Gapura website, observation and questionnaire will be done. During the observation, several tests was carried out such as a blur test to find out whether the most important thing is being highlighted correctly, pattern test to determine whether the reading direction and content of the site has been arranged well from the most important to the least important, as well as assessments on aesthetic design, information conveying method used, etc. in questionnaire (Eldesouky, 2013), (Soussan et al., 2011).

After determining the errors and faults, a prototype that would serve as a guidance of a better version of Gapura website will be made by using Axure RP 8 software. The prototype would then be reevaluated to people who have used the site Gapura before to determine whether the prototype is better than the current Gapura (Gardner, 2012).

\section{Results}

A. Analysis of Problems and Needs

Data collection was conducted to determine the problems in the UI of Gapura site by doing an observation and questionnaire based on the Web UI Design Best Practices (UXPin, 2017) book, and was asked to 197 new students from the Informatics Engineering Faculty of 2018 consisting of 71 Information Systems students, 71 Informatics Engineering students, 34 Computer System students, 9 Physics Engineering students and 12 Electrical Engineering students.

Questions and scenarios given in the process of observation and questionnaires are:

1. On the blur test, "Where did your eyes first go when you see this blurry image?"

2. In the test scenario, "If you want to borrow a room through the Gate site, what will you do?"

The statements given in the survey are:

1. "UI Gapura is attractive."

2. "The UI of Gapura website makes it easy for users to use."

The survey respondents then answered the above statements using a Likert Scale to show how they agreed to these statements with a description of scale 1 strongly disagree and scale 5 strongly agree.

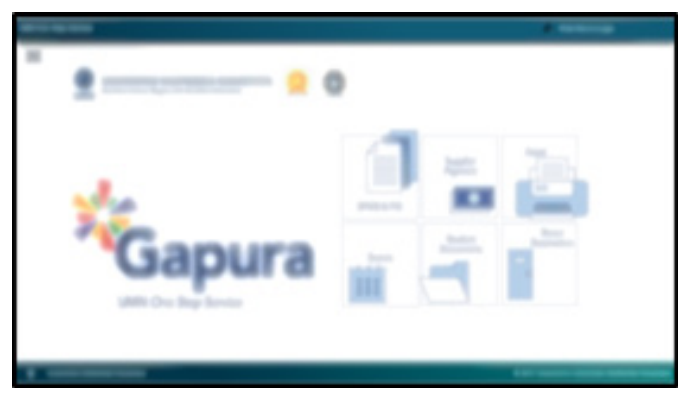

Figure 1. Blur Test

(Source: gapura.umn.ac.id)

Figure 1 is the blur test that we shared to the respondents while filled in the questionnaires. Figure 2 is the result of observation test was then grouped into 5 points:

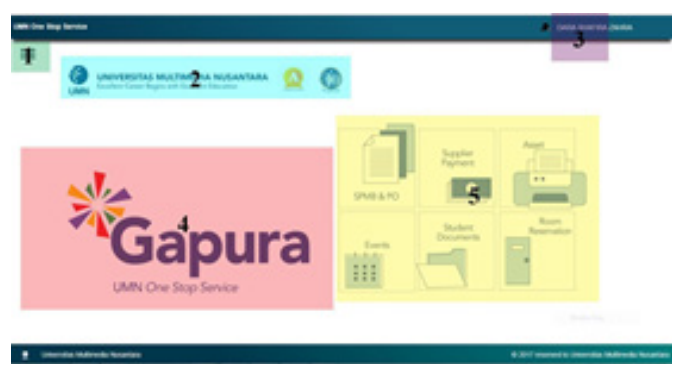

Figure 2. Result Grouping Points (Source: gapura.umn.ac.id) 
Dara Shafira Zahra ${ }^{1}$

Wella $^{2}$

Aditya Satyagraha ${ }^{3}$
User Interface Analysis of Gapura

UMN Website
B. Analysis Results

Table 1. Blur Test Result

\begin{tabular}{|c|c|c|c|c|c|c|}
\hline \multicolumn{7}{|c|}{ Blur Test } \\
\hline \multirow[b]{2}{*}{ Majors } & \multicolumn{5}{|c|}{ Area } & \multirow[t]{2}{*}{ TOTAL } \\
\hline & 1 & 2 & 3 & 4 & 5 & \\
\hline $\begin{array}{l}\text { Information } \\
\text { Systems }\end{array}$ & 1 & $\begin{array}{l}1 \\
3\end{array}$ & 7 & $\begin{array}{l}3 \\
2\end{array}$ & $\begin{array}{l}1 \\
8\end{array}$ & 71 \\
\hline $\begin{array}{l}\text { Informatics } \\
\text { Engineerin } \\
\mathrm{g}\end{array}$ & 3 & $\begin{array}{l}1 \\
5 \\
\end{array}$ & 6 & $\begin{array}{l}3 \\
5 \\
\end{array}$ & $\begin{array}{l}1 \\
2 \\
\end{array}$ & 71 \\
\hline $\begin{array}{l}\text { Computer } \\
\text { System }\end{array}$ & 4 & 2 & 3 & $\begin{array}{l}2 \\
0\end{array}$ & 5 & 34 \\
\hline $\begin{array}{l}\text { Electrical } \\
\text { Engineerin } \\
\mathrm{g}\end{array}$ & 0 & 1 & 1 & 8 & 2 & 12 \\
\hline $\begin{array}{l}\text { Physics } \\
\text { Engineerin } \\
\mathrm{g}\end{array}$ & 0 & 0 & 1 & 4 & 4 & 9 \\
\hline TOTAL & 8 & $\begin{array}{l}3 \\
1\end{array}$ & $\begin{array}{l}1 \\
8\end{array}$ & $\begin{array}{l}9 \\
9\end{array}$ & $\begin{array}{l}4 \\
1\end{array}$ & 197 \\
\hline Percentage & $\begin{array}{l}4 \\
\%\end{array}$ & $\begin{array}{l}1 \\
6 \\
\%\end{array}$ & $\begin{array}{l}9 \\
\%\end{array}$ & $\begin{array}{l}5 \\
0 \\
\%\end{array}$ & $\begin{array}{l}2 \\
1 \\
\%\end{array}$ & $100 \%$ \\
\hline
\end{tabular}

Table 2. Scenario Test Result

\begin{tabular}{|c|c|c|c|c|c|c|}
\hline \multicolumn{7}{|c|}{ Scenario Test } \\
\hline \multirow[b]{2}{*}{ Majors } & \multicolumn{5}{|c|}{ Area } & \multirow[t]{2}{*}{ TOTAL } \\
\hline & 1 & 2 & 3 & 4 & 5 & \\
\hline $\begin{array}{l}\text { Information } \\
\text { Systems }\end{array}$ & 2 & 0 & 1 & 0 & 68 & 71 \\
\hline $\begin{array}{l}\text { Informatics } \\
\text { Engineerin } \\
\mathrm{g}\end{array}$ & 4 & 5 & 0 & 0 & 62 & 71 \\
\hline $\begin{array}{l}\text { Computer } \\
\text { System }\end{array}$ & 0 & 0 & 0 & 0 & 34 & 34 \\
\hline $\begin{array}{l}\text { Electrical } \\
\text { Engineerin } \\
\mathrm{g}\end{array}$ & 1 & 0 & 1 & 0 & 10 & 12 \\
\hline $\begin{array}{l}\text { Physics } \\
\text { Engineerin } \\
\mathrm{g}\end{array}$ & 0 & 0 & 0 & 0 & 9 & 9 \\
\hline TOTAL & 7 & 5 & 2 & 0 & $\begin{array}{l}18 \\
3 \\
\end{array}$ & 197 \\
\hline Percentage & $\begin{array}{l}4 \\
\% \\
\end{array}$ & $\begin{array}{l}3 \\
\% \\
\end{array}$ & $\begin{array}{l}1 \\
\%\end{array}$ & $\begin{array}{l}0 \\
\%\end{array}$ & $\begin{array}{l}93 \\
\% \\
\end{array}$ & $100 \%$ \\
\hline
\end{tabular}

Table 3. Questionnaire Result

\begin{tabular}{|c|c|c|c|c|c|c|}
\hline \multicolumn{7}{|c|}{ "UI of Gapura is Attractive" } \\
\hline \multirow{2}{*}{ Majors } & \multicolumn{5}{|c|}{ Likert Scale } & \multirow{2}{*}{$\begin{array}{l}\text { Tota } \\
1\end{array}$} \\
\hline & 1 & 2 & 3 & 4 & 5 & \\
\hline $\begin{array}{l}\text { Informatio } \\
\text { n Systems }\end{array}$ & 32 & 13 & 19 & 5 & 2 & 71 \\
\hline $\begin{array}{l}\text { Informatic } \\
\text { s } \\
\text { Engineerin }\end{array}$ & 13 & 15 & 30 & 7 & 6 & 71 \\
\hline $\begin{array}{l}\text { Computer } \\
\text { System }\end{array}$ & 0 & 1 & 4 & 0 & 4 & 9 \\
\hline $\begin{array}{l}\text { Electrical } \\
\text { Engineerin } \\
\mathrm{g}\end{array}$ & 3 & 5 & 4 & 0 & 0 & 12 \\
\hline $\begin{array}{l}\text { Physics } \\
\text { Engineerin }\end{array}$ & 5 & 3 & 8 & 16 & 2 & 34 \\
\hline TOTAL & 53 & 37 & 65 & 28 & 14 & 197 \\
\hline $\begin{array}{l}\text { Percentag } \\
\mathrm{e}\end{array}$ & $\begin{array}{l}27 \\
9 \% \\
\end{array}$ & $\begin{array}{l}19 \\
96\end{array}$ & $\begin{array}{l}33 \\
96 \\
\end{array}$ & $\begin{array}{l}14 \\
96\end{array}$ & $7 \%$ & $\begin{array}{l}100 \\
9 \% \\
\end{array}$ \\
\hline \multicolumn{7}{|c|}{ "UI of Gapura Malies It Easy to Use for Users" } \\
\hline \multirow{2}{*}{ Majors } & \multicolumn{5}{|c|}{ Likert Scale } & $\begin{array}{l}\text { Tota } \\
1\end{array}$ \\
\hline & 1 & 2 & 3 & 4 & 5 & \\
\hline $\begin{array}{l}\text { Informatio } \\
\text { n Systems }\end{array}$ & 31 & 9 & 17 & 10 & 4 & 71 \\
\hline $\begin{array}{l}\text { Informatic } \\
\text { s } \\
\text { Engineerin } \\
\mathrm{g}\end{array}$ & 22 & 11 & 11 & 20 & 7 & 71 \\
\hline $\begin{array}{l}\text { Computer } \\
\text { System }\end{array}$ & 0 & 2 & 1 & 5 & 1 & 9 \\
\hline $\begin{array}{l}\text { Electrical } \\
\text { Engineerin } \\
\mathrm{g}\end{array}$ & 4 & 7 & 1 & 0 & 0 & 12 \\
\hline $\begin{array}{l}\text { Physics } \\
\text { Engineerin } \\
\mathrm{g}\end{array}$ & 8 & 18 & 5 & 1 & 9 & 34 \\
\hline TOTAL & 65 & 47 & 35 & 38 & 12 & 197 \\
\hline $\begin{array}{l}\text { Percentag } \\
\mathrm{e}\end{array}$ & $\begin{array}{l}33 \\
9 \% \\
\end{array}$ & $\begin{array}{l}24 \\
9 \% \\
\end{array}$ & $\begin{array}{l}18 \\
9 \% \\
\end{array}$ & $\begin{array}{l}19 \\
96 \\
\end{array}$ & $6 \%$ & $\begin{array}{l}100 \\
9 \%\end{array}$ \\
\hline
\end{tabular}

From the data obtained, it can be concluded that the look of the site gate does not have a good visual hierarchy and is difficult for the user to understand at the first time of use. In addition, the majority of users also argue that the look of the Archway site is mediocre and is hard to use for users.

C. Persona 
Persona is an important method for directing the design and development team to the user experience in the form of user examples created by the UI / UX designer to find out the types of users who will use their products (Floyd et al., 2008). Persona of this research could be seen on Figure 3 .

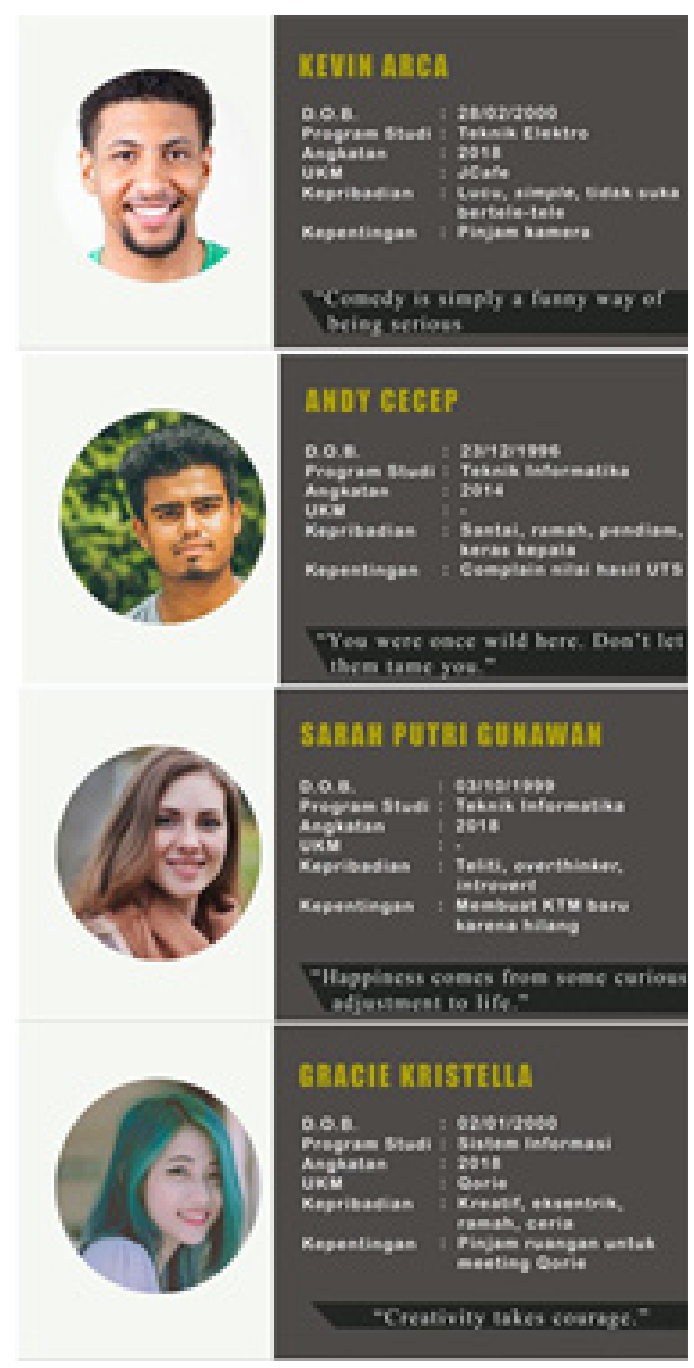

Figure 3. Persona

(Source: Matthews et al., 2012)

\section{User Scenario}

User Scenario is a scenario carried out by personas who achieve their goals on the site. The user scenario describes the activities, things that must be considered in order to make the personas comfortable in using the site and ideas that can be used in the design process.

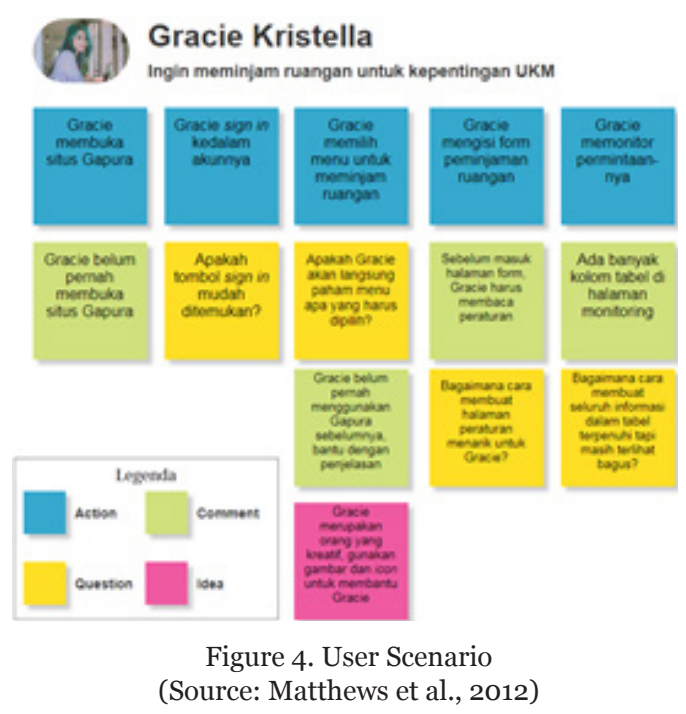

Figure 4 is the list of user scenario. In the user scenario of a persona named Gracie Kristella who has an interest in borrowing a room, explained that she had never opened and used the Gapura site. Ideally, a site should be able to directly be understood by users, even by first time users. In this case, the question arises, "How does Gracie know that the first thing she has to do is enter her account?" And, "Is the sign in button easy to find?". So, the sign in button must have good contrast so that it can be seen by the user.

Next, Gracie will choose a menu to borrow the room. Gracie has never opened the gate before, so the problem arose, "Will Gracie understand which menu she should choose?" In addition, explained in the person profile that Gracie is someone who has a creative nature, the use of pictures, photos or icons will be one of the first things Gracie will see. Therefore, in addition to using explanations for each menu, using the right icons and images 
can really help Gracie.

Then, Gracie will fill out the reservation form. However, before that Gracie had to read the rules for borrowing the room first. As explained earlier, Gracie is a creative person, and the use of images/ visual elements will greatly help Gracie. Therefore, the regulation page can be decorated with images related to the rules of writing so that it can still get Gracie's attention so that he will read all the rules from beginning to end.

Finally, Gracie will monitor her request. On the monitoring page that Gapura has now, there is a long table containing columns that look very plain. Gracie is a creative person who likes things that are visually beautiful. So, the monitoring page display must be made in such a way as to look beautiful while still having all the information in the table in the current Gapura site monitoring display

\section{E. Visual Arrangement}

The Visual Arrangement is the basis of the Visual Hierarchy and UI patterns of site views. Brown (2012), trying to focus on more than one thing at the same time triggers a feeling of stress, however humans can take in more information that is presented peripherally; in a way that allows individuals to assess whether they need to give more attention or not.

Canva (2018), all in all, an ideal visual arrangement has to be able to guide its users properly, deliver the connection between each content in the website, and trigger a pleasant emotional connection with its users.

\section{F. UI Pattern of Gapura Website}

The pattern that will be the focus of the evaluation of this study consists of site reading patterns and contrast that will highlight things that are at the highest priority level on a website page. The UI pattern of the Gapura website prototype will be arranged in accordance with the results of the current Gapura site review.

Based on the way the elements on the main page of the Gapura website are arranged, it appears that the page is designed to be read in pattern $\mathrm{F}$ (Figure 5). However, because the main view of the site shows an image in the middle of the page, the user reads the $\mathrm{Z}$ page pattern (Figure 6) and misses the menu button, which causes the user mistakes in menu selection as shown in the results of the scenario test.

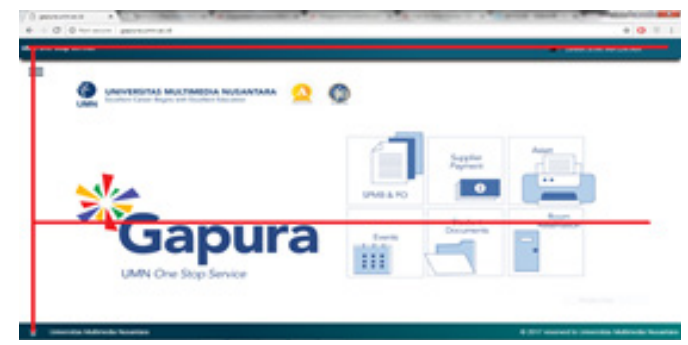

Figure 5. Expectation of Gapura Website Reading Pattern.

(Source: gapura.umn.ac.id)

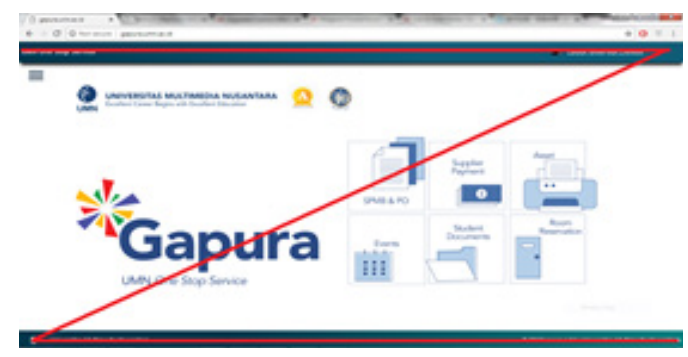

Figure 6. How the Gapura Website is Really Read by the Users.

(Source: gapura.umn.ac.id)

After knowing from the blur test that the majority of users' attention was focused on the logo of the gate, it was then decided that a $\mathrm{Z}$ pattern would be used as it would focus the users on the logo, but also provide a place for the menu in the reading pattern so that users would not miss them. The result of prototype's reading pattern can be seen on Figure 7 . 


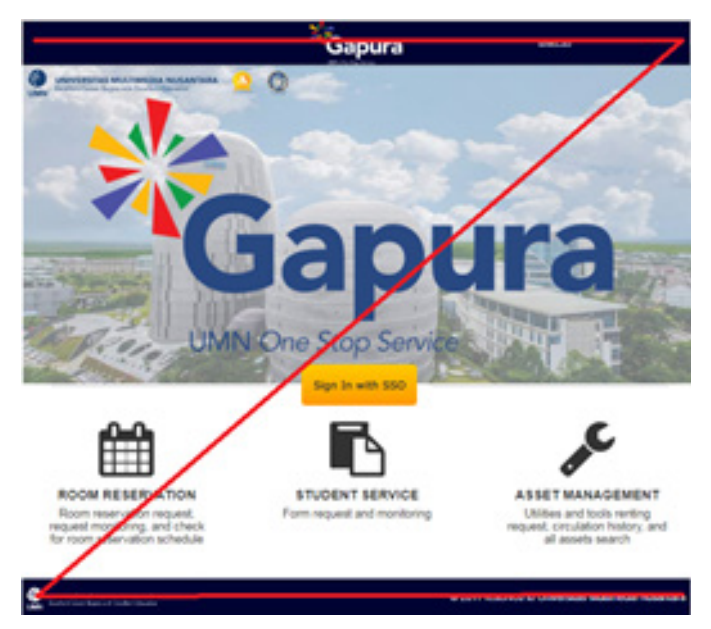

Figure 7. Prototype's Reading Pattern.

(Source: gapura.umn.ac.id

In addition, it is then known that other pages of the other Gapura website are also arranged in a reading pattern F. Unfortunately, because Gapura is a site that mostly contains lists of rules, it is difficult to make the appearance interesting and attractive to the users. Therefore, the site prototype will be made in mostly Z-reading pattern to give the impression that there isn't much writings in the content and the user can share their attention at each reading point.

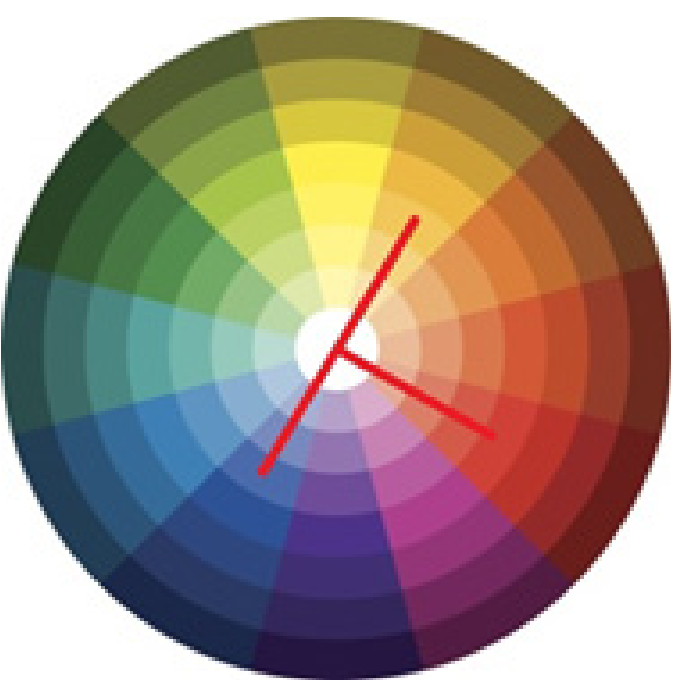

Figure 8. Colour Combination Used in Gapura (Source: Weinschenk, 2011)
Furthermore, Gapura site uses analog colour combinations, like Figure 8 showed (Trevor van Gorp \& Edie Adams, 2012). This explains the cause of the lack of contrast found on the Gate site because analog colour combinations are used to produce harmony between elements (Weinschenk, 2011).

The palette used in the prototype uses complementary colour combinations that function to highlight contrast on a display (Figure 9). By using this colour combination, it is expected that the contrast in the prototype will be more visible so as to create a clearer display of visual hierarchy.

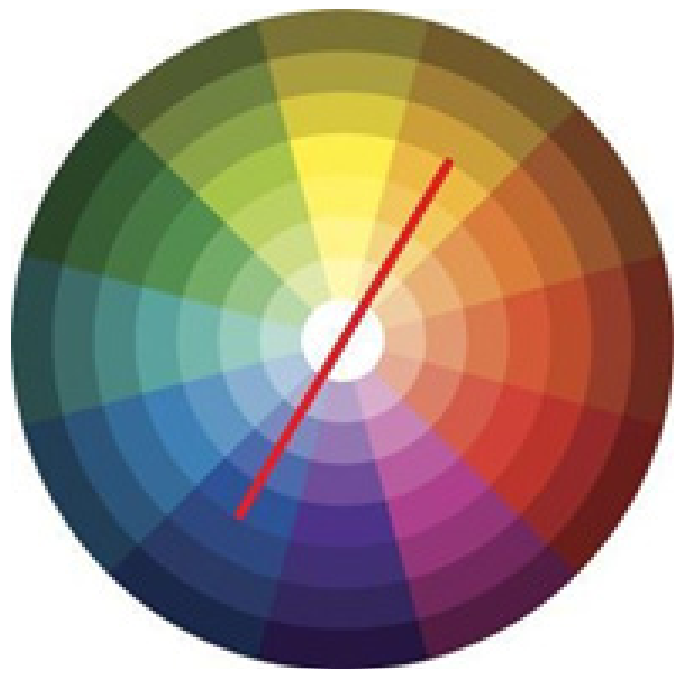

Figure 9. Colour Combination Used in Prototype (Source: Weinschenk, 2011)

\section{G. Prototype Creation}

The prototype was made using Axure RP 8, following the direction of UXPin's UI Best Practice e-book.

On Figure 10, the main page of the Gapura site prototype, the user is directed to enter their account. The menu on the page cannot be used before doing so. After the user successfully sign in, Figure 11 and 12 will be seen by the user. 
Dara Shafira Zahra ${ }^{1}$

Wella $^{2}$

Aditya Satyagraha ${ }^{3}$

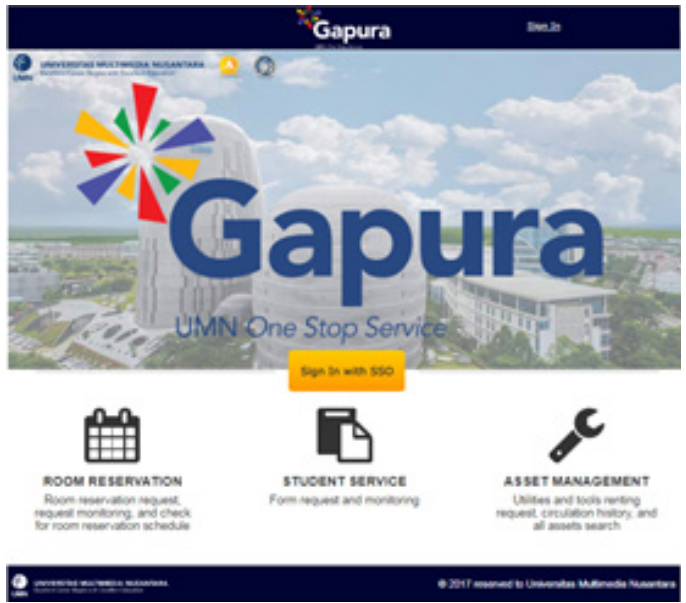

Figure 10. Main Page of the Prototype Before Signing In.

(Source: gapura.umn.ac.id)

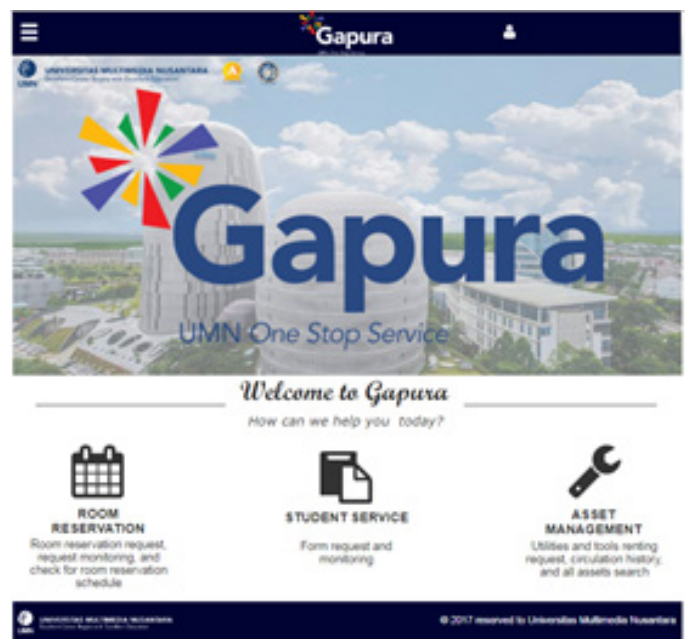

Figure 11. Main Page of the Prototype After Signing In (Source: gapura.umn.ac.id)

Figure 13 shows that users can use the menu below or the hamburger menu located at the top left of the page to start using the site.

In order to create a UI design that maintains the simple, clean, and beautiful look that's still capable of cramming a lot of information in one page, monitoring pages in the prototype are designed as such in exchange for the current Gapura's

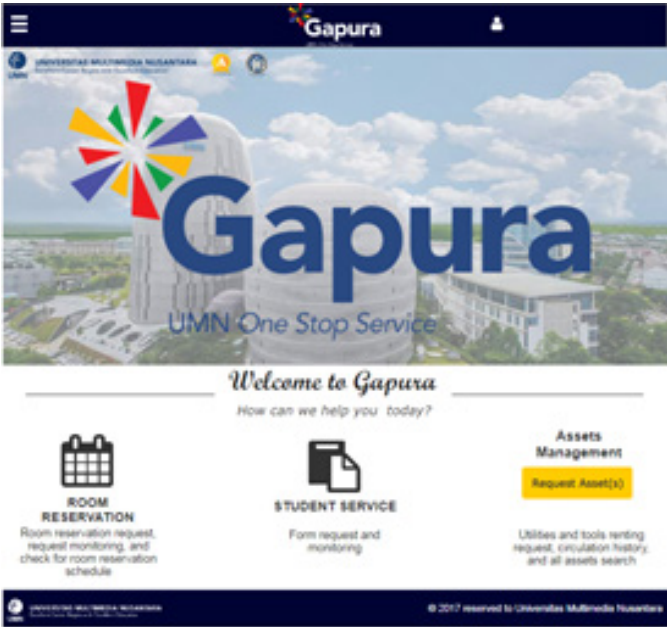

Figure 12. Menus' Appearance when User's Cursor Hovers Over Them

(Source: gapura.umn.ac.id)

tables (Figure 17).

On Figure 14 explained that each menu on the prototype has a main page to give more explanation on each menu by directing the cursor on the menu image so that users can better understand the functions of each menu. Further explanation appears when the cursor hovers over the menu to save space and keep them looking clean and neat.

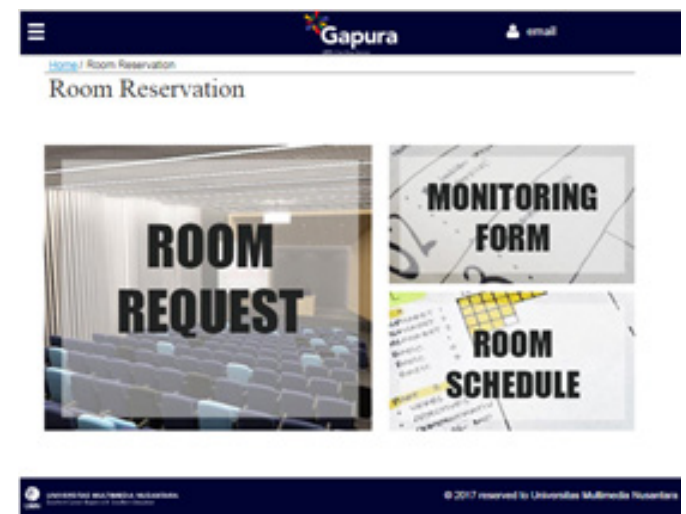

Figure 13. Main Page of Room Reservation Menu (Source: gapura.umn.ac.id)

On Figure 15, user could see the rules are arranged in a $\mathrm{Z}$ pattern to divide the 


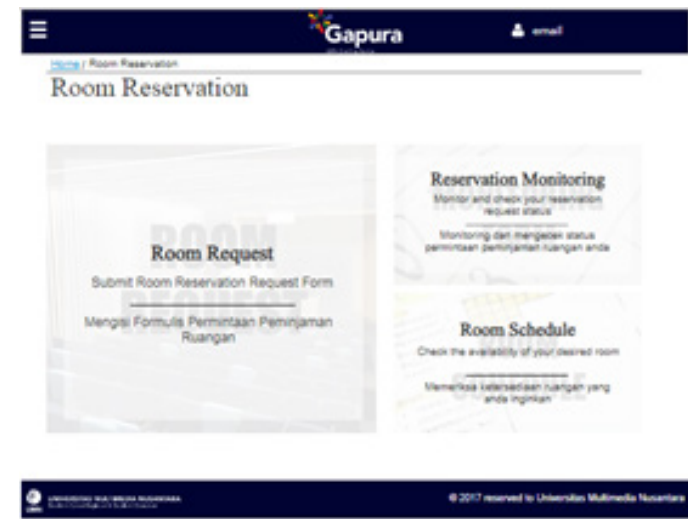

Figure 14. Explanation of Each Menu in Room Reservation Page

(Source: gapura.umn.ac.id)

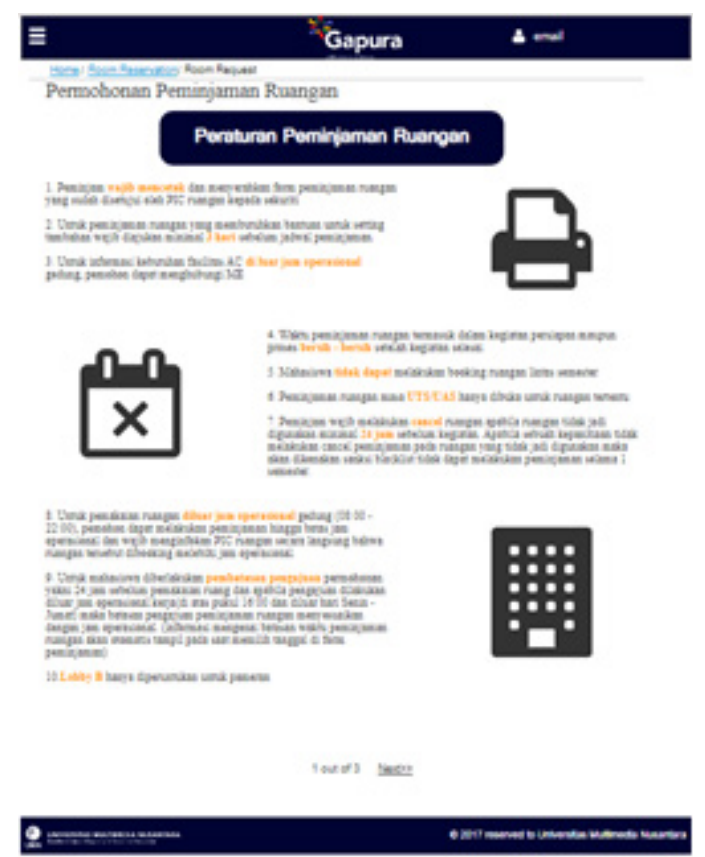

Figure 15. Rules Page

(Source: gapura.umn.ac.id)

user's attention and to not bore users.

The request form menu page is designed to look simple and not crowded as it displays translation of the form's terms and conditions in English (Figure 16). Explanation of each form option can be seen by choosing the desired form request option.
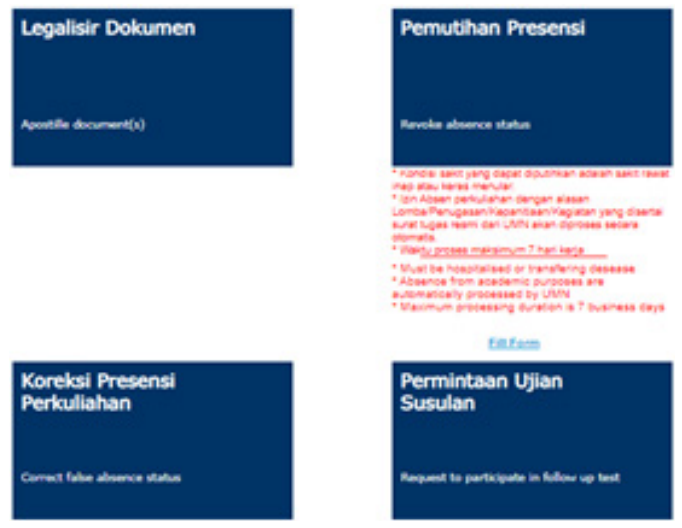

Figure 16. Terms and Conditions for Each Requests are in Bilingual

(Source: gapura.umn.ac.id)
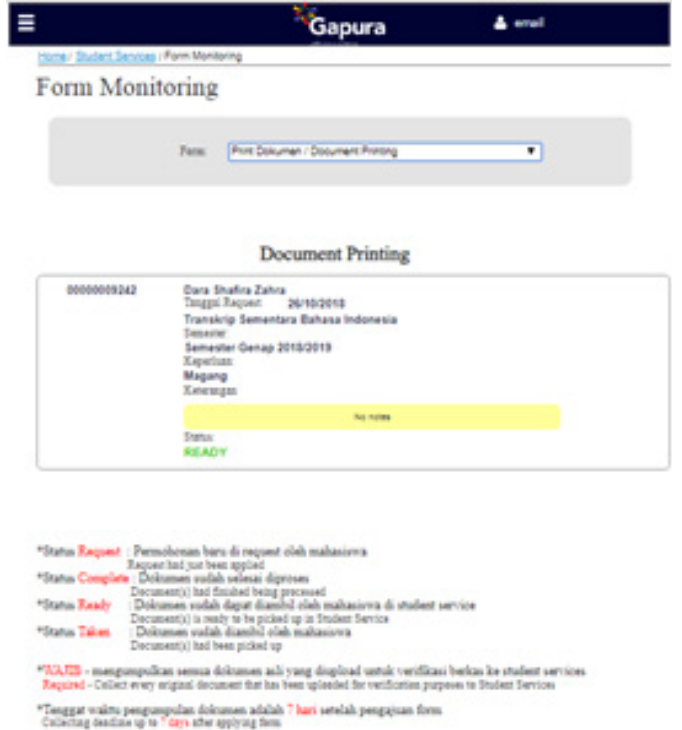

Figure 17. Monitoring Menu's UI (Source: gapura.umn.ac.id)

\section{Discussions}

The evaluation of the prototype was done to 40 participants who have all used the Gapura website previously to see if the prototype has better UI than the current Gapura. Like the initial evaluation conducted to the Gapura website, the evaluation methods used to the prototype are blur test, scenario test, and questionnaire. 
Dara Shafira Zahra ${ }^{1}$

Wella $^{2}$

Aditya Satyagraha ${ }^{3}$

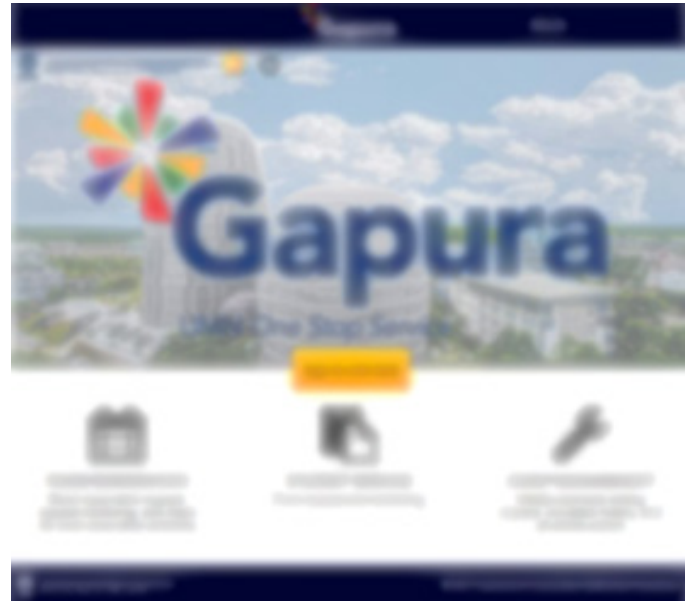

Figure 18. Blur Test of the Prototype (Source: gapura.umn.ac.id)

Areas were then assigned to each points in the prototype.

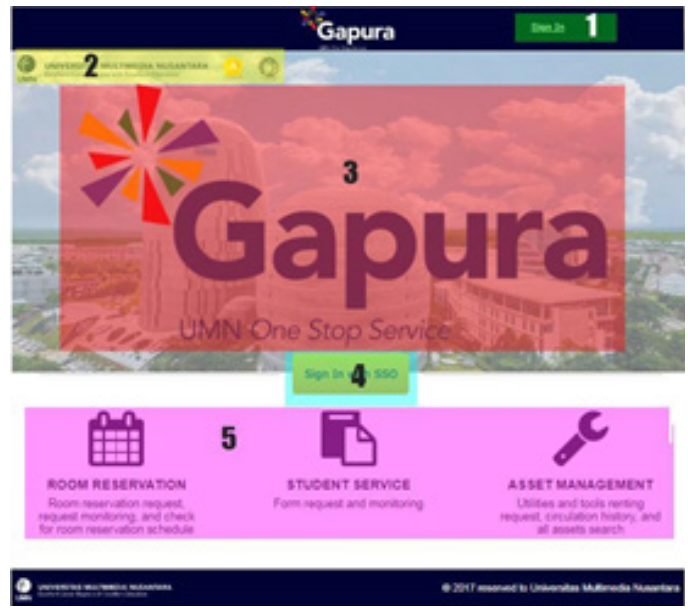

Figure 19. Areas of the Prototype Blur Test (Source: gapura.umn.ac.id)

From the scenario test, 38 out of 40 participants went straight to the menu area on the main page, while the other 2 went to the hamburger menu from the left top of the page.

This shows that although visual hierarchy-wise the Gapura prototype still has the same visual hierarchy as the current Gapura website's, the prototype is proven to be more understandable to the users, and more attractive and easier for the users to use.

Table 4. Prototype's Blur Test Result

\begin{tabular}{|c|c|c|c|c|c|c|}
\hline \multicolumn{7}{|l|}{ Blur Test } \\
\hline & \multicolumn{6}{|c|}{ Area } \\
\hline & $\mathbf{1}$ & 2 & 3 & 4 & 5 & $\begin{array}{l}\text { Tot } \\
\text { al }\end{array}$ \\
\hline $\begin{array}{l}\text { Participa } \\
\text { nts' Sum }\end{array}$ & 1 & 0 & $\begin{array}{l}2 \\
4\end{array}$ & 12 & 3 & 40 \\
\hline $\begin{array}{l}\text { Percenta } \\
\text { ge }\end{array}$ & $\begin{array}{l}3 \\
\%\end{array}$ & $\begin{array}{l}\text { o } \\
\%\end{array}$ & $\begin{array}{l}6 \\
0 \\
\%\end{array}$ & $\begin{array}{l}3 \\
\mathbf{0} \\
\%\end{array}$ & $\begin{array}{l}8 \\
\%\end{array}$ & $\begin{array}{l}100 \\
\%\end{array}$ \\
\hline
\end{tabular}

Table 5. Questionnaire Result

\begin{tabular}{|l|l|l|l|l|l|l|}
\hline \multicolumn{7}{|c|}{ "Prototype's UI is more attractive" } \\
\hline & \multicolumn{2}{|c|}{ Likert Scale } \\
\hline & 1 & $\mathbf{2}$ & $\mathbf{3}$ & $\mathbf{4}$ & $\mathbf{5}$ & $\begin{array}{l}\text { Tot } \\
\text { al }\end{array}$ \\
\hline $\begin{array}{l}\text { Particip } \\
\text { ants' } \\
\text { sum }\end{array}$ & & & & & & \\
\hline & & & 5 & 22 & 12 & 40 \\
\hline $\begin{array}{l}\text { Percent } \\
\text { age }\end{array}$ & $\mathbf{0}$ & $\mathbf{3}$ & $\mathbf{1 3}$ & $\mathbf{5 5}$ & $\mathbf{0}$ & $\mathbf{1 0}$ \\
& $\%$ & $\%$ & $\%$ & $\%$ & $\mathbf{0} \%$ \\
\hline
\end{tabular}

"Prototype's UI is easier to use than Gapura"

\begin{tabular}{|l|l|l|l|l|l|l|}
\hline & \multicolumn{6}{|c|}{ Likert Scale } \\
\hline & 1 & 2 & 3 & 4 & 5 & $\begin{array}{l}\text { Tot } \\
\text { al }\end{array}$ \\
\hline $\begin{array}{l}\text { Particip } \\
\text { ants' } \\
\text { sum }\end{array}$ & 0 & 0 & 4 & 17 & 19 & 40 \\
\hline & & & & & 4 & \\
Percent & 0 & 0 & 10 & 43 & 8 & 10 \\
age & $\%$ & $\%$ & $\%$ & $\%$ & $\%$ & $0 \%$ \\
\hline
\end{tabular}




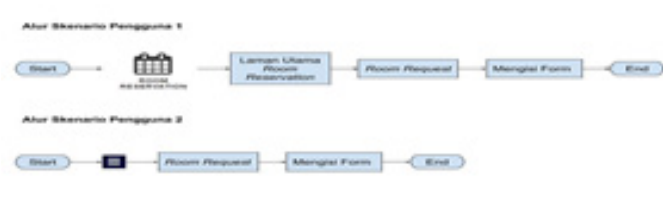

Figure 20. Prototype's Scenario Test Result

\section{Conclusions}

By looking at the results of the study, the author concluded that:

1. The Prototype of the Gapura Website still contains errors in terms of the visual hierarchy.

2. The Gapura prototype can be better understood by users.

3. The Gapura prototype received better feedback from the Gapura site's users.

\section{Future Work}

The suggestions that can be given during this study are:

1. To create a wireframe with software that has a simple format before prototyping.

2. To use prototyping software that is better than Axure RP8, and if possible create a prototype manually to avoid glitches on the prototype.

\section{Referensi}

Eldesouky, D. F. (2013). Visual Hierarchy and Mind Motion in Advertising Design. Journal of Arts and Humanities (JAH), 148-162.

Floyd, I. R., Jones, C., \& Twidalel, M. B. (2008). Resolving Incommensurable Debates: A Preliminary Identifications of Persona Kinds, Attributes, and Characteristics. ARTIFACT, 12-26.
Gardner, B. S. (2012). Responsive Web Design:Enriching the User Experience.

Matthews, T., Judge, T. K., \& Whittaker, S. (2012). How Do Designers and User Experience Professionals Actually Perceive and Use Personas? Proceedings of the SIGCHI Conference on Human Factors in Computing Systems, 1219-1228.

Rouse, M. (2016, November). User Interface(UI). Retrieved from TechTarget: https://searchmicroservices.techtarget.com/definition/user-interface-UI

Sonderegger, A. \& Sauer, J. (2009). The Influence of Design Aesthetics in Usability Testing Effects on User Per-formance and Perceived Usability.

Soussan Djamasbi, Marisa SIegel, Jeanine Skorinko \& Tom Tullis. (2011). Online Viewing and Aesthetic Preferences of Generation Y and the Baby Boom Generation: Testing User Web Site Experience Through Eye Tracking.

Stephanie. (2012, May 14). Slovin's Formula: What is it and When do I use it? Retrieved from Statistic How To: https://www.statisticshowto. datasciencecentral.com/how-to-useslovins-formula/

Trevor van Gorp \& Edie Adams. (2012). Design for Emotion. Waltham: Elsevier.

Tugui, A. (2011). Calm Technologies: A New Trend for Educational Technologies.

UXPin. (2014). Web UI Design Patterns 2014: A Deeper Look At the Hottest Websites and Web Apps Today. Retrieved from UXPin: https://www. uxpin.com/studio/ebooks/web-design-patterns/ 


\section{Aditya Satyagraha ${ }^{3}$}

UXPin. (2015). The Ultimate Guide to Prototyping. Retrieved from UXPin: https://www.uxpin.com/studio/ebooks/guide-to-prototyping/

UXPin. (2017). Web UI Design Best Practices. Retrieved from UXPin: https:// www.uxpin.com/studio/ebooks/webui-design-best-practices/

Weinschenk, S. (2011). 100 Things Every Designer Needs to Know about People. Berke-ley: New Riders. 